\title{
KEJAHATAN PERSETUBUHAN TERHADAP ANAK ARGUMENTASI KONSEP DUALISTIS PERTANGGUNGJAWABAN HUKUM PIDANA
}

\author{
Chessa Ario Jani Purnomo \\ Fakultas Hukum Universitas Pamulang \\ E-mail : dosen02258@unpam.ac.id
}

\begin{abstract}
Abstrak
Majelis Hakim perkara pidana nomor 51/Pid.Sus/2016/PN.Kbu telah memutus bebas Terdakwa atas nama Febri Anggara alias Angga Bin Heri Nugroho terhadap dakwaan dan tuntutan sebelas (11) tahun pidana penjara oleh Penuntut Umum berdasarkan Pasal 81 ayat (2) Undang-Undang 35 tahun 2014. Sebelumnya, Terdakwa didakwa dengan dakwaan alternatif sebagai berikut: Kesatu, Pasal 81 ayat (1) Jo. Pasal 76D Undang-Undang Nomor 35 Tahun 2014 Jo. Pasal 64 KUHP. Kedua, Pasal 81 ayat (2) Undang-Undang 35 tahun 2014 Jo. Pasal 64 KUHP. Ketiga, Pasal 82 ayat (1) Jo. Pasal 76E Undang-Undang Nomor 35 Tahun 2014 Jo. Pasal 64 KUHP. Persidangan pidana dalam perkara a quo yang diketuai oleh Arief Hakim Nugraha sebelum mencapai konklusi ditenggarai mencerminkan tiga hal: Pertama, penerapan ajaran dualistis dalam hukum pidana yang memisahkan secara tegas perbuatan pidana dan pertanggungjawaban pidana. Kedua, perihal parameter pembuktian dalam hukum pidana. Ketiga, perihal konsep perlindungan hak-hak Terdakwa dalam perspektif hak asasi manusia, khususnya isu fair trial. Penelitian ini menggunakan metode normatif-yuridis atau doctrinal research yang bersifat preskriptif. Penulis menggunakan pendekatan kasus (case approach). Bahan hukum primer dalam penelitian ini yakni putusan Pengadilan Negeri Kotabumi nomor 51/Pid.Sus/2016/PN.Kbu. Selanjutnya, bahan hukum sekunder menggunakan buku (ilmu) hukum pidana dan jurnal hukum terkait isu yang relevan. Penelitian ini menemukan konsistensi logika hukum (ratio decidendi) Majelis Hakim dalam mengkonstruksi hukum dalam perkara pidana konkret terkait penerapan konsep perlindungan hak-hak terdakwa (hak asasi manusia), penerapan teori dualistis serta interpretasi dalam hukum pidana dan penerapan alat bukti yang sah menurut ajaran hukum pidana formil.
\end{abstract}

Kata Kunci : perbuatan pidana; pertanggungjawaban pidana; hak asasi.

\section{Abstract}

Criminal case number 51/Pid.Sus/2016/PN.Kbu has decided the acquittal of the Defendant on behalf of Febri Anggara alias Angga Bin Heri Nugroho for the eleven (11) years imprisonment by the Public Prosecutor based on Article 81 paragraph (2) of Law 35 year 2014. Previously, the Defendant was charged with alternative charges as follows: Firstly, Article 81 paragraph (1) Jo. Article 76D of Law Number 35 Year 2014 Jo. Article 64 of the Criminal Code. Secondly, Article 81 paragraph (2) of Law 35 of 2014 Jo. Article 64 of the 
Criminal Code. Thirdly, Article 82 paragraph (1) Jo. Article $76 E$ Law Number 35 Year 2014 Jo. Article 64 of the Criminal Code. Criminal proceedings in the a quo case chaired by Arief Hakim Nugraha before reaching a conclusion are suspected to reflect three things: Firstly, the application of dualistic teachings in criminal law that clearly separates criminal acts and criminal liability. Secondly, regarding the parameters of proof in criminal law. Thirdly, regarding the concept of protecting the rights of the Defendant in the perspective of human rights, specifically the issue of fair trial. This research uses normative-juridical method or prescriptive doctrinal research. The author uses a case approach. The primary legal material in this study is the decision of Kotabumi District Court number 51 / Pid.Sus / 2016 / PN.Kbu. Furthermore, secondary legal material uses criminal law books (science) and legal journals related to relevant issues. This research found the consistency of legal logic (ratio decidendi) of the Panel of Judges in constructing the law in concrete cases related to the application of the concept of protection of defendant rights (human rights), the application of dualistic theory and interpretation in criminal law and the application of valid evidence according to formal criminal law teachings.

Keywords: Criminal acts; criminal liability; human rights.

\section{Pendahuluan}

Hakim Arief telah memvonis bebas (vrijspraak) Terdakwa atas nama Febri Anggara alias Angga Bin Heri Nugroho terhadap tuntutan sebelas (11) tahun pidana penjara oleh Penuntut Umum berdasarkan Pasal 81 ayat (2) Undang-Undang Nomor 35 tahun 2014. ${ }^{1}$ Terdakwa dilaporkan oleh Anak SaksiSaksi Korban (17 tahun) sendiri atas tuduhan persetubuhan terhadap anak, yang nanti Hakim Arief akan mempertimbangkan (laporan pidana) untuk sampai kepada konklusi putusannya. Terdakwa didakwa dengan dakwaan alternatif yakni: Kesatu, Pasal 81 ayat (1) Jo. Pasal 76D Undang-Undang Nomor 35 Tahun 2014 Jo. Pasal 64 KUHP. Kedua, Pasal 81 ayat (2) UndangUndang 35 tahun 2014 Jo. Pasal 64 KUHP. Ketiga, Pasal 82 ayat (1) Jo. Pasal 76E Undang-Undang Nomor 35 Tahun 2014 Jo. Pasal 64 KUHP. Titulus est lex Pasal 76D undang-undang a quo, perbuatan yang dilarang berbunyi demikian: "setiap orang dilarang melakukan Kekerasan atau ancaman Kekerasan

${ }^{1}$ Lihat, periksa, dan baca Putusan Pengadilan Negeri Kotabumi, Pidana Khusus, Nomor 52/Pid.Sus/2016/PN.Kbu, Febri Anggara Alias Angga Bin Heri Nugroho, 26 Juni 2016, hlm. 2. 
memaksa Anak melakukan persetubuhan dengannya atau dengan orang lain." Delik ini terdiri dari bestandeel ${ }^{2}$ sebagai berikut:

1. Setiap orang;

2. Melakukan kekerasan atau ancaman kekerasaan memaksa Anak melakukan peretubuhan dengannya atau dengan orang lain.

Dalam dakwaan kesatu, Pasal diatas di-jounto dengan Pasal 81 ayat (1) undang-undang a quo yang mengatur seperti ini: "setiap orang yang melangggar ketentuan sebagaimana dimaksud dalam Pasal 76D dipidana dengan pidana penjara paling singkat 5 (lima) tahun dan paling lama 15 (lima belas) tahun dan denda paling banyak Rp5.000.000.000,00 (lima miliar rupiah)."

Memperhatikan dakwaan kedua bahwa secara normatif-yuridis Pasal 81 ayat (2) menetapkan demikian: "ketentuan pidana sebagaimana dimaksud pada ayat (1) berlaku pula bagi setiap Orang yang dengan sengaja melakukan tipu muslihat, serangkaian kebohongan, atau membujuk Anak melakukan persetubuhan dengannya atau dengan orang lain." Bila dipecah maka delictbestandeelen-nya menjadi:

1. Setiap orang;

2. Melakukan tipu muslihat, serangkaian kebohongan, atau membujuk anak melakukan persetubuhan dengannya atau dengan orang lain;

Selanjutnya, dakwaan ketiga penuntut umum bersandar pada Pasal 76E undang-undang a quo, dengan ketentuan: "Setiap Orang dilarang melakukan Kekerasan atau ancaman Kekerasan, memaksa, melakukan tipu muslihat, melakukan serangkaian kebohongan, atau membujuk Anak untuk melakukan atau membiarkan dilakukan perbuatan cabul." Pasal ini dapat diurai sebagai berikut:

1. Setiap orang;

2. Melakukan Kekerasan atau ancaman Kekerasan, memaksa, melakukan tipu muslihat, melakukan serangkaian kebohongan, atau membujuk Anak untuk melakukan atau membiarkan dilakukan perbuatan cabul.

Pada dakwaan kesatu bahwa penuntut umum berupaya menguraikan perbuatan Terdakwa dalam surat dakwaan berdasarkan Pasal 81 ayat (1) Jo. Pasal 76D Undang-Undang Nomor 35 Tahun 2014 Jo. Pasal 64 KUHP. Unsur waktu terjadinya tindak pidana dan unsur tempat terjadinya tindak pidana sebagai syarat formil dakwaan tidak luput didalilkan.

${ }^{2}$ Bahwa terdapat perbedaan prinsip tentang arti kata element dan bestandeel dalam perbuatan pidana. Element perbuatan pidana meliputi unsur yang tertulis dan unsur yang tidak tertulis, sedangkan bestandeel hanya meliputi unsur perbuatan pidana yang tertulis saja. Lihat Eddy O. S. Hiearij, Prinsip .... op.cit., hlm., 129. 
la berargumen bahwa Terdakwa melakukan perbuatan persetubuhan dengan cara menjanjikan pernikahan kepada Anak Korban pada hari Minggu tanggal 11 Oktober 2015 pukul 14.00 WIB. ${ }^{3}$ Selanjutnya, dakwaan kedua penuntut umum menyatakan bahwa perbuatan Terdakwa melanggar Pasal 81 ayat (2) Undang-Undang 35 tahun 2014 Jo. Pasal 64 KUHP. ${ }^{4}$ Terakhir, dakwaan ketiga penuntut umum mendalilkan bahwa perbuatan Terdakwa melanggar Pasal 82 ayat (1) Jo. Pasal 76E Undang-Undang Nomor 35 Tahun 2014 Jo. Pasal 64 KUHP. ${ }^{5}$ Secara mutatis mutandis penuntut umum menuduh Terdakwa melakukan perbuatan pencabulan terhadap anak. Melihat konstruksi dakwaan penuntut umum yang bersifat alternatif ${ }^{6}$ maka pada titik ini secara teoritik, penuntut umum dalam kondisi keraguan-raguan (in dubio). Meskipun pada akhirnya penuntut umum dalam tuntutannya menjatuhkan perbuatan Terdakwa berdasarkan dakwaan kedua melanggar Pasal 81 ayat (2) UndangUndang 35 tahun 2014 Jo. Pasal 64 KUHP, sebagai berikut:

“1. Menyatakan Terdakwa Febri Anggara Alias Angga Bin Heri Nugroho, terbukti bersalah melakukan tindak pidana "persetubuhan terhadap Anak di bawah umur" sebagaimana dakwaaan ke-2 kami melanggar Pasal 81 ayat (2) Undang-Undang 35 tahun 2014 Jo. Pasal 64 KUHP tentang Perubahan Undang-Undnag R.I. No. 23 Tahun 2002 Tentang Perlindungan Anak; 2. Menjatuhkan pidana terhadap Terdakwa Febri Anggara Alias Angga Bin Heri Nugroho dengan pidana penjara 11 (sebelas) tahun dikurangi selama Terdakwa berada dalam tahanan, dengan perintah Terdakwa tetap dtahan dan Pidana dengan sebesar Rp. 60.000.000,- (enam puluh juta rupiah) Subsidair 2 (dua) bulan kurungan";

Berdasarkan pemeriksaan alat bukti keterangan saksi, alat bukti keterangan Terdakwa, alat bukti surat dan alat bukti petunjuk Majelis Hakim berargumentasi: pertama, bahwa tempus delicti dan locus delicti dinyatakan terjadi pada Minggu di bulan Oktober 2015 sekira pukul 14.00 WIB di rumah Saudara Aan yang beralamat di Desa Trimodadi Kec. Abung Selatan Kab.

3 Ibid., Putusan Pengadilan Negeri Kotabumi, Pidana Khusus, Nomor 52/Pid.Sus/2016/PN.Kbu, Febri Anggara Alias Angga Bin Heri Nugroho, 26 Juni 2016, hlm. 3 $\mathrm{s} / \mathrm{d} 6$.

4 Ibid., Putusan Pengadilan Negeri Kotabumi, Pidana Khusus, Nomor 52/Pid.Sus/2016/PN.Kbu, Febri Anggara Alias Angga Bin Heri Nugroho, 26 Juni 2016, hlm. 6 s/d 9 .

5 Ibid., Putusan Pengadilan Negeri Kotabumi, Pidana Khusus, Nomor 52/Pid.Sus/2016/PN.Kbu, Febri Anggara Alias Angga Bin Heri Nugroho, 26 Juni 2016, hlm. 9 s/d 11 .

${ }^{6}$ Dalam perkembangan praktik bentuk dakwaan terbagi dalam lima jenis meliputi surat dakwaan tunggal, subsidiaritas, alternatif, kumulatif, dan kombinasi. Periksa Surat Edaran Jaksa Agung Republik Indonesia Nomor SE-004/J.A/11/1993 tentang Pembuatan Surat Dakwaan.

loc.cit., Putusan Pengadilan Negeri Kotabumi, Pidana Khusus, Nomor 52/Pid.Sus/2016/PN.Kbu, Febri Anggara Alias Angga Bin Heri Nugroho, hlm. 2. 
Lampung Utara Terdakwa telah menyetubuhi anak korban. Kedua, tidak ada saksi fakta berkenaan dengan ia yang melihat, mendengar dan mengetahui (Testimonium de Auditu) yang diajukan oleh Penuntut Umum terhadap fakta materiil atas perbuatan Terdakwa. Khususnya, terhadap penilaian Hakim Arief atas dakwaan ke-2 Penuntut Umum berdasarkan Pasal 81 ayat (2) UndangUndang 35 tahun 2014 Jo. Pasal 64 KUHP. Ketiga, Makelis Hakim dalam mencari dasar pemidanaan Terdakwa menilai kata "sengaja" dalam dakwaan Penuntut Umum menggunakan teori willens en wetens. Teori ini mensyaratkan bahwa setiap perbuatan melekat padanya kehendak dan pengetahuan. Namun Hakim Arief tidak meng-eksplore lebih jauh perihal isu ini. Keempat, bahwa Majelis Hakim menafsirkan kata "persetubuhan" dalam dakwaan Penuntut Umum dengan merujuk pendapat R. Soesilo yang pada intinya peraduan antara penis laki-laki kedalam vagina perempuan sehingga mengeluarkan air mani. Namun Hakim Arief menginterpretasikan kata "persetubuhan" bahwa peraduan antara penis laki-laki kedalam vagina perempuan tidak sampai terjadi ejakulasi atau mengeluarkan air mani, yang dalam hal ini perbuatan Terdakwa terhadap anak saksi-saksi korban. Kelima, bahwa Majelis Hakim mengkonstruksikan asas hukum anak berhadap-hadapan dengan asas perlindungan warga negara dalam bingkai negara hukum. la di mana dengan menilai unsur-unsur delik (delichtbestandeelen) dalam surat dakwaan Penuntut Umum, menghasilkan pertimbangan yang berimbang.

Akhirnya, pada bagian amar putusan Majelis Hakim menyatakan secara negatif bahwa Terdakwa tidak terbukti secara sah dan meyakinkan bersalah melakukan tindak pidana dan membebaskan Terdakwa dari segala dakwaan penuntut umum. Lengkapnya, penulis kutip demikian:

“1. Menyatakan Terdakwa Febri Anggara Alias Angga Bin Heri Nugroho tersebut di atas, tidak terbukti secara sah dan meyakinkan bersalah melakukan tindak pidana sebagaimana didakwakan dalam dakwaan alternatif kesatu, alternatif kedua dan alternatif ketiga Penuntut Umum; 2. Membebaskan Terdakwa oleh karena itu dari semua dakwaan Penuntut Umum. ${ }^{8}$

\section{Permasalahan}

Berdasarkan uraian di atas, maka diperoleh rumusan masalah sebagai berikut Pertama, bagaimana konsep perbuatan pidana dan pertanggungjawaban pidana dalam putusan nomor 51/Pid.Sus/2016/PN.Kbu ? Kedua, bagaimana majelis hakim pidana membangun argumentasinya dalam perkara pidana nomor 51/Pid.Sus/2016/PN.Kbu?

8 Ibid., Putusan Pengadilan Negeri Kotabumi, Pidana Khusus, Nomor 52/Pid.Sus/2016/PN.Kbu, Febri Anggara Alias Angga Bin Heri Nugroho, hlm. 40. 


\section{Metode Penelitian}

Penulisan artikel ini menggunakan metode yuridis normatif atau doctrinal research atau penelitian kepustakaan yang bersifat preskriptif. Penulis menggunakan pendekatan kasus (case approach). Bahan hukum primer dalam artikel ini adalah perkara pidana putusan nomor 51/Pid.Sus/2016/PN. Kbu. Kemudian, bahan hukum sekunder terdiri dari bukubuku hukum pidana, hukum acara pidana, dan hukum pembuktian dan atau jurnal, laporan penelitian yang relevan terhadap isu. Bahan hukum tersier terdiri dari kamus besar bahasa indonesia (online). Penulis menganalisis bahan-bahan hukum itu guna menjelaskan dan menemukan asas-asas hukum pidana dan atau ilmu hukum pidana terhadap putusan hakim pidana a quo.

\section{Pembahasan}

\section{Konsep Perbuatan Pidana dan Pertanggungjawaban Pidana Dalam Putusan Nomor 51/Pid.Sus/2016/PN.Kbu}

Tulisan dalam artikel ini akan berupaya membangun argumentasi dalam rangka menemukan asas-asas hukum pidana dihubungkan dengan ratio decidendi majelis hakim dalam perkara pidana nomor 51/Pid.Sus/2016/PN.Kbu. Pertama, Penulis akan membahas asas legalitas, perbuatan pidana dan konsep melawan hukum. Kedua, Penulis akan menyajikan pandangan para pakar hukum pidana terkait asas kesalahan dan pertanggungjawaban pidana. Ketiga, penulis akan menguraikan beberapa parameter pembuktian dan perspektif hak asasi manusia, khususnya prinsip fair trial.

Pada tulisan ini hendak mengemukakan makna asas legalitas dalam hukum pidana. Berangkat dari formula yang ditulis oleh Anselm von Feuerbach, seorang sarjana hukum Jerman (1755-1833) bahwa pertama ialah nulla poena sine lege: tidak ada pidana tanpa ketentuan pidana menurut undang-undang. Kedua, nulla poena sine criminine: tidak ada pidana tanpa perbuatan pidana. Terakhir, nullum crimen sine poena legali: tidak ada perbuatan pidana tanpa pidana menurut undang-undang. ${ }^{9}$ Postulat di atas juga dikenal dengan asas nullum delictum nulla poena sine praevia lege poenali (tiada perbuatan pidana tanpa undang-undang pidana sebelumnya). ${ }^{10}$

Menurut Komariah Emong Sapardjaja asas legalitas ada empat makna. Dua yang pertama ditujukan kepada pembuat undang-undang (de wetgevende macht), dan dua yang lainnya merupakan pedoman bagi hakim. Pertama,

${ }^{9}$ D. Schaffmeister, N. Keizer, dan E. PH. Sitorius, Hukum Pidana, Citra Aditya Bakti, Bandung, 2007, hlm., 5.

${ }_{10}$ Moeliono, T. P. (2015). Asas Legalitas dalam Hukum Acara Pidana: Kritikan terhadap Putusan MK tentang Praperadilan. Jurnal Hukum lus Quia lustum, 22(4), 594-616. 
bahwa pembuat undang-undang tidak boleh memberlakukan suatu ketentutan pidana berlaku surut. Kedua, bahwa semua perbutan yang dilarang harus dimuat dalam rumusan delik sejelas-jelasnya. Ketiga, hakim dilarang menyatakan bahwa terdakwa melakukan perbuatan pidana didasarkan pada hukum tidak tertulis atau hukum kebiasaan. Keempat, terhadap peraturan hukum pidana dilarang diterapkan analogi. ${ }^{11}$

Kemudian, menurut Schaffmeister, Keizer dan Sitorius ada tujuh aspek asas legalitas yang dapat dibedakan yakni pertama, tidak dapat dipidana kecuali berdasarkan ketentuan pidana menurut undang-undang. Kedua, tidak ada penerapan undang-undang pidana berdasarkan analogi. Ketiga, tidak dapat dipidana hanya berdasarkan kebiasaan. Keempat, tidak boleh ada perumusan delik yang kurang jelas (syarat lex certa). Kelima, tidak ada kekuatan surut dari undang-undang pidana. Keenam, tidak ada pidana lain kecuali yang ditentukan undang-undang. Ketujuh, penuntutan pidana hanya menurut cara yang ditentukan undang-undang. ${ }^{12}$ makna: ${ }^{13}$

Selanjutnya, Roeslan Saleh berpendapat bahwa asas legalitas memiliki

1. Tidak ada perbuatan yang dilarang dan diancam dengan pidana kalau hal itu terlebih dahulu belum dinyatakan dalam satu aturan undangundang.

2. Untuk menentukan adanya perbuatan pidana tidak boleh digunakan analogi.

3. Aturan-aturan hukum pidana tidak berlaku mundur.

Jadi, berdasarkan pendapat Roeslan, Komariah, Schaffmeister, Keizer dan Sitorius maka dapat ditarik kesimpulan sebagai berikut: Kesatu, tidak ada pidana pidana tanpa peraturan perundangan-undangan pidana. Kedua, tidak ada pidana tanpa peraturan perundang-undangan pidana yang jelas. Ketiga, tidak ada pidana tanpa peraturan perundang-undangan pidana yang ketat. Keempat, dengan demikian adanya jaminan atas kepastian hukum atau jaminan terkait fungsi proteksi terhadap hak asasi manusia. Kelima, sebagai konsekuensi turunan dari fungsi proteksi maka ada fungsi penuntutan pidana atau fungsi intrumentalis menurut asas oppurtunitas hanya oleh pemerintah berdasarkan peraturan perundang-undangan pidana.

Berikutnya, Penulis hendak mengemukakan pengertian perbuatan pidana "bahwa perbuatan pidana adalah perbuatan yang dilarang dan diancam

${ }^{11}$ Komariah Emong Sapardjaja, Ajaran Sifat Melawan-Hukum Materiel Dalam Hukum Pidana Indonesia, Alumni, 2002, hlm. 5-6.

${ }^{12}$ D. Schaffmeister, N. Keizer, dan E. PH. Sitorius, Hukum Pidana ..., op.cit., hlm., 7.

${ }^{13}$ Roeslan Saleh, Perbuatan Pidana dan Pertanggungjawaban Pidana: Dua Pengertian Dasar Dalam Hukum Pidana, Aksara Baru, 1983, hlm. 40. 
dengan pidana barangsiapa yang melakukannya", demikian kata Mahrus Ali. ${ }^{14}$ Bandingkanlah dengan pendapat Satochid Kartanegara dengan mengutip Simons, meski tidak memberi pengertian atau definisi namun menyatakan unsur-unsur perbuatan pidana sebagai berikut: ${ }^{15}$

1. Suatu perbuatan manusia (menslijk handelingen). Dengan handeling dimaksudkan tidak saja "een doen" (perbuatan), akan tetapi juga "een nalatten" (mengakibatkan);

2. Perbuatan itu (yaitu perbuatan dan mengabdikan) dilarang dan diancam dengan hukuman oleh undang-undang;

3. Perbuatan itu harus dilakukan oleh seseorang yang dipertanggungjawabkan, artinya dapat dipersalahkan karena melakukan perbuatan tersebut.

Perdefinisi, secara tegas bahwa Ali telah membatasi pengertian perbuatan pidana hanya pada perbuatan yang dilarang dan diancam dengan pidana. Sementara, Kartanegara dengan mengutip Simons telah mempersatukan bahkan mencampuradukan pengertian perbuatan pidana dengan pengertian pertanggungjawaban pidana dengan kata-kata “dipertanggungjawabkan" dan “dapat dipersalahkan”. Penulis menolak pendapat dari Kartanegara karena old style. Kemudian, elemen perbuatan pidana sebagaimana Moeljatno mengatakan bahwa: Kelakuan dan akibat (=perbuatan); hal ikhwal atau keadaan yang menyertai perbuatan; keadaan tambahan yang memberatkan pidana; unsur melawan hukum objektif; unsur melawan hukum subjektif. ${ }^{16}$

Penulis tidak akan menjelaskan satu per satu elemen perbuatan pidana dengan alasan keterbatasan ruang, kecuali unsur melawan hukum objektif dan unsur melawan hukum subjektif. Maka, pada bagian ini kiranya penting untuk melihat kritik yang dilancarkan oleh Hiearij kepada Moeljatno. Mula-mulanya Hiearij menjelaskan pengertian unsur melawan hukum objektif atau objektif onrechtselement sebagai perbuatan yang sangat jelas sekali memenuhi unsur delik. Sedangkan unsur melawan hukum subjektif atau subjektif onrechtselement merupakan niat atau sikap batin pelaku. Lengkapnya: ${ }^{17}$

“... saat menjelaskan mengenai perbuatan pidana, Moeljatno memisahkan secara tegas perbuatan pidana dan pertanggungjawaban pidana. Akan tetapi, ketika berbicara mengenai elemen-elemen perbuatan pidana, Moeljatno memasukan subjektif onrechstelement sebagai salah satu elemen. Menurut pendapat Penulis, berbicara

\footnotetext{
${ }^{14}$ Mahrus Ali, Dasar-Dasar Hukum Pidana, Sinar Grafika, Jakarta, 2011, hlm. 98.

${ }^{15}$ Satochid Kartanegara, Hukum Pidana, Balai Lektur Mahasiswa, tanpa kota, tanpa tahun, hlm. 65.

${ }^{16}$ Moeljatno, Asas-Asas ..., op.cit., hlm. 69.

${ }^{17}$ Eddy O. S. Hiearij, Prinsip .... op.cit., hlm. 127-128.
} 
mengenai subjektif onrechstelement, pada hakikatnya berbicara mengenai sikap batin atau niat atau mensrea pelaku yang merupakan dasar pertanggungjawaban pidana."

Selanjutnya, penulis hendak menguraikan konsep melawan hukum (wederrechtelijkheid) dalam hukum pidana. Ragam perspektif terkait isu ini dirasa cukup panjang, dapatlah dilihat sebagaimana berikut:

1. Moeljatno mengemukakan konsep melawan hukum terdiri dari: formal dan material; ${ }^{18}$

2. Eddy O. S. Hiearij menulis tiga konsep melawan hukum: Pandangan Formil, ${ }^{19}$ Pandangan Materiil ${ }^{20}$ dan Pandangan Tengah; $; 1$

3. Schaffmeister, Keizer dan Sitorius berpendapat konsep melawan hukum: sifat melawan hukum formal, sifat melawan hukum materiil, sifat melawan hukum umum dan sifat melawan hukum khusus; ${ }^{22}$

Penjelasan dari konsep melawan hukum formal ialah melawan hukum berarti melawan undang-undang, sebab hukum adalah undang-undang", kata Moeljatno. ${ }^{23}$ Sedangkan melawan hukum material “... disamping undangundang (hukum yang tertulis) ada pula hukum yang tidak tertulis, yaitu norma-norma atau kenyataan-kenyataan yang berlaku dalam masyarakat," masih menurut Moeljatno. ${ }^{24}$

Pengertian dari istilah melawan hukum berdasarkan dogmatik hukum pidana, memiliki empat makna yang berbeda-beda. Adapun empat makna tersebut berdiri dari: ${ }^{25}$

1. Melawan hukum umum, diartikan sebagai syarat tidak tertulis untuk dapat dipidana. -melawan hukum suatu tindak pidana berdasarkan perbuatan melawan hukum umum, tidak perlu dibuktikan namun harus dilaksanakan oleh pelaku tindak pidana.

${ }^{18}$ Moeljatno, Asas-Asas ..., op.cit., hlm. 140-141.

${ }^{19}$ Bagi Hiearij bahwa melawan hukum formil bersifat problematis ketika ia mengkritisi pendapat seorang pakar hukum pidana Belanda, Pompe. Dimana pada pokoknya, melawan hukum menjadi unsur yang menentukan ada atau tidaknya suatu perbuatan pidana dalam rumusan delik. Padahal tidak semua rumusan delik ada kata-kata "melawan hukum". Lihat Eddy O. S. Hiearij, Prinsip .... op.cit., hlm. 226.

${ }^{20}$ Sebaliknya, Hiearij menolak pandangan melawan hukum materiil sebab dalam level implementasi Penuntut Umum akan memikul kewajiban dengan ketat untuk melakukan pembuktian perihal unsur melawan hukum apabila nyata-nyata ada pada setiap rumusan delik. Lihat Eddy O. S. Hiearij, Prinsip .... Ibid., hlm. 229.

${ }^{21}$ Bahwa Hiearij lebih menerima pandangan tengah dalam isu melawan hukum. Lihat Eddy O. S. Hiearij, Prinsip .... Ibid., hlm., 231.

${ }_{22}$ D. Schaffmeister, N. Keizer, dan E. PH. Sitorius, Hukum Pidana ..., op.cit., hlm. 49.

\footnotetext{
${ }^{23}$ Moeljatno, Asas-Asas ..., op.cit., hlm. 140.

${ }_{25}^{24}$ Moeljatno, Asas-Asas ..., Ibid., hlm. 141.

${ }^{25}$ Anisah, S., \& Raharjo, T. (2018). Batasan Melawan Hukum dalam Perdata dan
} Pidana pada Kasus Persekongkolan Tender. lus Quia lustum Law Journal, 25(1), 24-48. 
2. Melawan hukum khusus, dirumuskan dalam delik, sehingga menjadi syarat tertulis untuk dapat dipidana. Melawan hukum berfungsi untuk dibuktikan dalam unsur tindak pidana.

3. Melawan hukum formil, terjadi bila seluruh rumusan delik dari undang undang terpenuhi. Melawan hukum formal merupakan syarat untuk dapat dipidana perbuatan dengan bersumber pada asas legalitas.

4. Melawan hukum materiil, melanggar atau membahayakan kepentingan hukum yang hendak dilindungi oleh pembentuk undang-undang dalam rumusan delik tertentu.

Kiranya penting dan tidak lengkap bilamana Penulis tidak menguraikan metode penemuan hukum, dalam hal ini jenis-jenis interpretasi yang dikenal dalam ilmu hukum pada umumnya yang secara mutatis mutandis berlaku dalam hukum pidana. Maka, siapapun yang membaca teks undang-undang (hukum tertulis) sebetulnya, melakukan interpretasi terhadap teks itu.

Maka, menyajikan pandangan Sudikno Mertoksumo perihal metode penemuan hukum menjadi ranah yang tidak dapat terpisahkan, khususnya ketika Hakim pidana menghadapi kasus konkret. Sudikno menyebut dua jenis metode penemuan hukum yakni interpretasi restriktif ${ }^{26}$ dan interpretasi ekstensif. ${ }^{27}$ Pendapat Sudikno ini terinspirasi dengan konsep judge made law negara common law. ${ }^{28}$

Sementara Eddy. O. S. Hiearij berpendapat dengan agak rinci dan terdapat empat jenis penafsiran hukum: ${ }^{29}$

“... Pertama, interpretasi gramatik yaitu makna ketentuan undangundang yang ditafsirkan dengan cara menguraikannya menurut bahasa umum sehari-hari. Kedua, interpretasi sistematis atau logis yakni penafsiran ketentuan perundang-undangan dengan menghubungkannya dengan peraturan hukum atau undang-undang lain atau keseluruhan sistem hukum. Ketiga, interpretasi historis adalah penafsiran makna undang-undang menurut terjadinya dengan jalan meneliti sejarah terjadinya perundang-undnagan tersebut. Keempat, interpretasi teleologis atau sosiologis bahwa interpretasi ini lebih menafsirkan undang-undang sesuai dengan tujuan pembentuk undang-undang daripada bunyi kata-kata dari undangundang tersebut."

Berdasarkan uraian teoritik di atas, maka penulis hendak menganalisis dengan memilah-milah pertimbangan Majelis Hakim perkara pidana a quo

${ }^{26}$ Sudikno Mertokusumo, Penemuan Hukum Sebuah Pengantar, Liberty, Yogyakarta, 2009, hlm. 63.

${ }_{27}^{27}$ Sudikno Mertokusumo, Penemuan ... Ibid., hlm. 64.

${ }^{28}$ Ramadhan, C. (2018). Konvergensi Civil Law dan Common Law di Indonesia dalam Penemuan dan Pembentukan Hukum. Mimbar Hukum-Fakultas Hukum Universitas Gadjah Mada, 30(2), 213-229.

${ }^{29}$ Eddy O. S. Hiearij, Asas Legalitas \& Penemuan Hukum Dalam Hukum Pidana, Erlangga, Jakarta, 2009, hlm. 66-67. 
yang dianggap menarik bahwa delictsbestandeelen Pasal 76D Undang-Undang No. 35 Tahun 2014, sebagaimana dakwaan kesatu Penuntut Umum dapat dipecah, yakni: "setiap orang" dan "melakukan Kekerasan atau ancaman Kekerasan memaksa Anak melakukan persetubuhan dengannya atau dengan orang lain."

Frasa kekerasan dan ancaman kekerasan menjadi fokus Hakim Arief, seperti: ${ }^{30}$

“... Menimbang, bahwa yang dimaksud dengan kekerasan artinya mempergunakan tenaga atau kekuatan jasmani tidak kecil secara tidak sah misalnya memukul dengan tangan atau dengan segala macam senjata, menyepak, menedang, dan sebagainya. Yang disamakan dengan melakukan kekerasan ialah membuat orang pingsan atau tidak berdaya lagi (lemah). Menimbang, bahwa yang dimaksud dengan melakukan ancaman kekerasan artinya mengeluarkan katakata atau gerakan-gerakan anggota tubuh baik kaki ataupun tangan, baik menggunakan sesuatu alat ataupun tidak, yang dapat menyebabkan atau memberi kekhawatiran kepada orang yang diancam tersebut sehingga menjadi takut dan mengikuti keinginan orang yang mengancam."

Kutipan di atas adalah upaya Hakim Arief mengkonstruksikan makna dari 'kekerasan' dan 'ancaman kekerasan'. Mencermati rumusan delik Pasal 76D 76D Undang-Undang No. 35 Tahun 2014 yang terdapat bagian inti delik 'kekerasan' dan 'ancaman kekerasan' mengingatkan kita dengan Pasal 285 KUHP. ${ }^{31}$ Namun apabila kita rujuk Pasal 287 ayat (1) KUHP ${ }^{32}$ yang pada pokoknya mengatur perkosaan terhadap anak di bawah umur, tidak ada bagian inti delik 'kekerasan' dan 'ancaman kekerasan'. Jadi, pembentuk undangundang masih meridhoi Pasal 76D Undang-Undang No. 35 Tahun 2014 itu dengan bagian inti delik 'kekerasan' dan 'ancaman kekerasan.'

\footnotetext{
30 Putusan Pengadilan Negeri Kotabumi, Pidana Khusus, Nomor 52/Pid.Sus/2016/PN.Kbu, Febri Anggara Alias Angga Bin Heri Nugroho, hlm. 26 s/d 27.

${ }^{31}$ Pasal 285 KUHP berbunyi: "Barangsiapa dengan kekerasan atau ancaman kekerasan memaksa seorang wanita bersetubuh dengan dia di luar pernikahan, diancam karena melakukan perkosaan, dengan pidana penjara paling lama dua belas tahun". Lihat Kitab Undang-Undang Hukum Pidana, penj. Moeljatno, Bumi Aksara, Jakarta, 2016, hlm. 105.

32 Pasal 287 KUHP mengatur: "Barangsiapa bersetubuh dengan seorang wanita di luar pernikahan, padahal diketahui atau sepatutnya harus diduga, bahwa umurnya belum lima belas tahun, atau kalau umurnya tidak ternyata, bahwa belum mampu dikawin, dianca, dengan pidana penjara paling lama sembilan tahun." Ibid., Kitab Undang-Undang Hukum Pidana, penj. Moeljatno, Bumi Aksara, Jakarta, 2016, hlm. 105.
} 
Penulis mengutip Andi Hamzah untuk membantu memperkaya wawasan kita perihal arti kata 'kekerasan' dan 'ancaman kekerasan, seperti di bawah ini: ${ }^{33}$

“... bagian inti delik perkosan harus dengan kekerasan atau ancaman kekerasan cocok dengan bahasa Indonesia "perkosaan" yang menurut kamus umum bahasa Indonesia 1976 susunan Poerwadarminto, ia mengatakan bahwa perkosaan berarti: 1. Menundukan dengan kekerasan; menggagahi, memaksa dengan kekerasan, misalnya memperkosa istri orang, memperkosa gadis yang belum berumur; 2 . Melanggar, menyerang, dan sebagainya dengan kekerasan."

Selanjutnya, ratio decidendi Hakim Arief yang patut Penulis diskusikan yakni: ${ }^{34}$

“... Menimbang, bahwa oleh karena itu Majelis Hakim berpendapat persetubuhan adalah perpaduan antara kemaluan laki-laki dan perempuan dimana kemaluan laki-laki masuk kedalam kemaluan perempuan meskipun tidak sampai terjadi ejakulasi atau mengeluarkan air mani pada diri laki-laki tersebut."

Bahwa sesungguhnya pertimbangan hukum Majelis Hakim sebagaimana kutipan di atas telah menggunakan interpretasi ekstensif dan bukan analogi terhadap makna persetubuhan. Dasar argumentasinya, pertama, Hakim Arief tidak mengubah redaksi Pasal 76D Undang-Undang No. 35 Tahun 2014 in casu a quo. Dengan mengingat asas legalitas dalam maknanya yang lex stricta maka sebagai konsekuensinya tidak diperbolehkan menerapkan analogi. Sementara, interpretasi ekstensif bukanlah analogi. Kedua, penafsiran ekstensif adalah suatu metode penemuan hukum dengan cara melampaui kata-kata terhadap metode interpretasi gramatikal oleh Hakim. Secara exofficio, Hakim dapat membuat pilihan dalam rangka memutus suatu perkara konkret berdasarkan metode penemuan hukum. Bertolak dari pemikiran di atas, Penulis berpendapat Hakim Arief tidak melampaui kewenangan legislatif perihal membuat norma baru dan tidak dapat dituduh mengikuti prinsip preseden $^{35}$ dalam common law system.

${ }^{33}$ Andi Hamzah, Delik-Delik Tertentu (Speciale Delicten) di dalam KUHP, Sinar Grafika, Jakarta, 2015, hlm. 21.

34 Ibid., Putusan Pengadilan Negeri Kotabumi, Pidana Khusus, Nomor 52/Pid.Sus/2016/PN.Kbu, Febri Anggara Alias Angga Bin Heri Nugroho, hlm. 27 dan 31.

${ }_{35}$ Asas preseden yaitu Hakim terikat pada putusan terdahulu yang serupa, yang membuat putusan pengadilan menjadi salah satu sumber hukum dikenal pada common law. Lihat, Ibid., Ramadhan, C. (2018). Konvergensi Civil Law dan Common Law di Indonesia dalam Penemuan dan Pembentukan Hukum. Mimbar Hukum-Fakultas Hukum Universitas Gadjah Mada, 30(2), 213-229. 
Adapun pertimbangan Hakim Arief yang problematis adalah: ${ }^{36}$

“... Menimbang, bahwa berdasarkan keterangan saksi Edi Suprianto dihubungkan dengan keterangan saksi Evi Cristiani dan saksi Ahmad Rivai bahwa saksi Saksi Korban berprofesi sebagai penyanyi orgen yang perilaku kehidupannya sehari-hari kurang baik yang pernah menganggu suami orang dan sering di bawa laki-laki ... menimbang, bahwa menurut pendapat Majelis Hakim walaupun anak saksi Saksi Korban seorang anak yang masih berumur 17 tahun akan tetapi perilaku kehidupan kesehariannya sudahlah bukan anak-anak yang masih polos dan anak saksi Korban sudah mengerti perbuatan benar dan salah."

Kritik penulis secara keseluruhan dalam pertimbangan hakim di atas pertama, Hakim Arief dalam membangun argumentasi telah menggunakan dimensi sosial dalam menilai fakta-fakta hukum dalam konteks profesi anak korban sebagaimana anak kalimat "penyanyi orgen" yang terkesan boros katakata. Kedua, sepanjang pemeriksaan di Pengadilan bahwa Hakim Arief memahami usia anak bukan lagi dari segi biologis atau dari segi normatifyuridis namun lebih kepada dimensi psikologis-sosial. Padahal kita mengetahui bahwa usia anak yang secara normatif-yuridis bervariasi, setidaknya dalam lapangan hukum pidana anak yakni 12-18 tahun. Jadi, bagi penulis sesungguhnya Hakim Arief pada bagian ini menggunakan model aliran pemikiran non dogmatis, bukan lagi sekadar jenis-jenis interpretasi sebagaimana tersebut di atas.

Kita mengetahui bahwa asas legalitas adalah altar suci dari perbuatan pidana, sementara asas kesalahan ialah pondasi dari pertanggungjawaban pidana. Pada sub judul ini Penulis hendak mengemukakan pandangan para pakar hukum pidana perihal asas culpabilitas dan pertanggungjawaban pidana (criminal liabilty). Menurut Eddy O. S. Hierij, kembali ke dalam magnus opusnya, yakni: ${ }^{37}$

“... Menurut hukum kita tdak ada kesalahan tanpa melawan hukum, teori ini kemudian diformulasikan sebagai: tiada pidana tanpa kesalahan atau geen straaf zonder schuld atau keine strafe ohne schuld (Jerman) atau actus non facit reum nisi mens sit rea atau actus reus mens rea (Latin). Asas ini merupakan dasar dari pertanggungjawaban pidana dan tidak ditemukan dalam undangundang. Ada juga postulat lain yang berbunyi nemo punitur sine injuria, facto seu defalta. Artinya, tidak ada seorang pun yang dihukum kecuali ia telah berbuat salah."

36 Op.cit., Putusan Pengadilan Negeri Kotabumi, Pidana Khusus, Nomor 52/Pid.Sus/2016/PN.Kbu, Febri Anggara Alias Angga Bin Heri Nugroho, hlm. 40.

${ }^{37}$ Eddy O. S. Hiearij, Prinsip .... op.cit., hlm. 153. 
Bagi Moeljatno bahwa syarat untuk adanya kesalahan, Terdakwa harus: ${ }^{38}$

1. Melakukan perbuatan pidana (sifat melawan hukum);

2. Di atas umur tertentu mampu bertanggungjawab.

3. Mempunyai suatu bentuk kesalahan yang berupa kesengajaan atau kealpaan;

4. Tidak adanya alasan pemaaf.

Timbul pertanyaan, apa yang dimaksud dengan kesalahan? Sebelum Penulis sajikan pandangan para pakar hukum pidana bahwa konsep kesalahan merentang dalam perkembangan pemikiran hukum pidana klasik sampai hukum pidana kontemporer. Katakanlah, era hukum pidana klasik perihal kesalahan tidak mendapat tempat. Sebaliknya, dalam pandangan hukum pidana kontemporer terkait kesalahan menjadi primadona dalam isu pertanggungjawaban pidana. Tegasnya, ada suatu perubahan paradigma dari tatstrafrecht menjadi tat-taterstrafrecht. Dengan perkataan lain, dari hanya menitikberatkan pada perbuatan dan akibatnya saja, berubah ke arah memperhatikan orang atau pelakunya.

Mari kita menelaah lebih dalam, perhatikan pandangan Jan Remmelink berikut ini: ${ }^{39}$

“... Bagaimanapun juga, kita tidak rela membebankan derita pada orang lain, sekadar karena orang itu melakukan tindak pidana, kecuali jika kita yakin bahwa ia memang dapat dipersalahkan karena tindakannya itu. Karena itu, kesalahan adalah pencelaan yang ditujukan oleh masyarakat -yang menerapkan standar etis yang berlaku pada waktu tertentu- terhadap manusia yang melakukan perilaku menyimpang yang sebenarnya dapat dihindari."

Pendapat Remmelink di atas dikomentari oleh Hanafi Amrani dan Mahrus Ali seperti di bawah ini: ${ }^{40}$

“... Apa yang dikemukakan oleh Remmelink tersebut menunjukan bahwa terbuktinya tindak pidana tidak secara otomatis pelakunya akan dijatuhi pidana. Agar negara memiliki justifikasi teoritis menjatuhkan pidana kepada seseorang yang terbukti melakukan tindak pidana, pada diri orang tersebut harus terdapat kesalahan. Merupakan suatu bentuk kezaliman teoritis bila negara, melalui hakim, menjatuhkan pidana kepada kepada seseorang yang hanya

${ }^{38}$ Moeljatno, Asas-Asas ..., op.cit., hlm. 177.

39 Jan Remmelink, Hukum Pidana Komentar atas Pasal-Pasal Terpenting dari Kitab Undnag-Undang Hukum Pidana Belanda dan Padanannya Dalam Kitab Undang-Undang Hukum Pidana Indonesia, Gramedia Pustaka Utama, Jakarta, 2014, hlm. 142.

${ }^{40}$ Hanafi Amrani dan Mahrus Ali, Sistem Pertanggungjawaban Pidana Perkembangan dan Penerapan, Rajwali Pers, Jakarta, 2015, hlm. 23. 
terbukti melakukan perbuatan yang dilarang, sementara orang tersebut sama sekali tidak memiliki kesalahan."

Dalam pandangan Remmelink, apa yang dimaksud pada anak kalimat “pencelaan yang ditujukan oleh masyarakat?" Menurut Chairul Huda 'dapat dicela' memiliki dua pengertian: ${ }^{41}$

"Pertama, 'dapat dicela' berarti 'dapat dipertanggungjawabkan dalam hukum pidana'. Dalam hal ini kesalahan diberi makna dalam hubungannya dengan fungsi preventif hukum pidana. Kata 'dapat' disini menunjukan bahwa celaan atau pertanggungjawaban pidana itu hilang, jika pembuat mempunyai alasan penghapusan kesalahan.

Kedua, 'dapat dicela' dapat pula diartikan sebagai 'dapat dijatuhi pidana'. Dalam hal ini, kesalahan diberi makna dalam hubungannya dengan fungsi represif hukum pidana. Kata 'dapat' dalam hal ini menunjukan bahwa celaan atau penjatuhan pidana tidak harus selalu dilakukan hakim. Hakim dapat saja hanya mengenakan tindakan, sekalipun tindak pidana terbukti dan terdakwa bersalah melakukannya. Selain itu, dapat saja celaan atau penjatuhan pidana tidak dilakukan, jika hakim memutuskan memberi pengampunan (rechtelijk-pardon)."

Tersimpul dalam pandangan Chairul bahwa kesalahan segaris lurus dengan pertanggungjawaban. Tegasnya, bahwa kesalahan sama dengan pertanggungjawaban itu sendiri. Kartanegara memberi syarat toerekeningsvatbaar, yakni: ${ }^{42}$

1. Keadaan jiwa orang itu adalah sedemikian rupa, sehingga ia dapat mengerti atau tahu akan nilai dari perbuatnnya itu sehingga juga dapat mengerti akan akibat dari perbuatnnya;

2. Keadaan jiwa orang itu harus demikian rupa sehingga ia dapat menentukan kehendaknya terhadap perbuatan yang dilakukannya itu;

3. Orang itu harus sadar, insaf, bahwa perbuatannya yang dilakukannya itu adalah perbuatan yang dilarang atau tidak dapat dibenarkan, baik dari sudut hukum, masyarakat maupun dari sudut tata-susila.

Jadi, berdasarkan pendapat Remmelink, Hanafi Amrani dan Mahrus Ali serta Chairul Huda, dan Kartanegara di atas bahwa kesalahan erat kaitannya dengan pertanggungjawaban pidana dan secara terang adanya pergeseran paradigma dari konsep kesalahan psikologis (alasan penghapusan kesalahan) menjadi konsep kesalahan normatif (nilai-nilai etis dari sudut masyarakat).

41 Chairul Huda, Dari Tiada Pidana Tanpa Kesalahan Menuju Kepada Tiada Pertanggungjawaban Pidana Tanpa Kesalahan: Tinjauan Kritis Teori Pemisahan Tindak Pidana dan Pertanggungjawaban Pdana, Kencana, Jakarta, 2013, hlm. 77-78.

42 Satochid Kartanegara, Hukum ... op.cit., tanpa kota, tanpa tahun, hlm. 206. 


\section{Argumentasi Konsep Dualistis Pertanggungjawaban Hukum Pidana Pada Putusan Nomor 51/Pid.Sus/2016/PN.Kbu}

In casu a quo, dakwaan kedua Penuntut Umum berdasarkan Pasal 81 ayat (2) Undang-Undang 35 Tahun 2014 turut diperiksa serta dipertimbangkan oleh Majelis Hakim sebagaimana berikut ini: ${ }^{43}$

“... Menimbang, bahwa yang dimaksud dengan sengaja adalah Willens En Wetens yang artinya menghendaki dan mengetahui. Hal ini dapat memberi kesan bahwa seseorang dapat dianggap sengaja apabila berkehendak untuk melakukan dan mengetahui akibat dari perbuatan tersebut. Menimbang, bahwa dengan demikian pengertian dengan sengaja mengandung makna bahwa perbuatan tersebut dikehendaki oleh pelaku dan pelaku mengetahui akibat perbuatan tersebut, atau pengertian secara umum adalah setiap perbuatan yang disadari akibatnya oleh pelakunya."

Dalam melihat pertimbangan hukum di atas dihubungkan dengan konsep kesalahan dan pertanggungjawaban pidana, Penulis berpendapat bahwa pertama, Hakim Arief menyebut secara expressive verbis istilah 'willen en weten' sama dengan 'sengaja' dengan tidak menguraikan lebih dalam. Sebetulnya istilah serupa dikritik oleh E. Utrecht sebagai berikut: ${ }^{44}$

“Apakah 'sengaja' itu? Menurut Crimineel Wetboek tahun 1809 (pasal 11), maka 'sengaja' itu maksud membuat sesuatu atau tidak membuat sesuatu yang dilarang atau diperintahkan oleh undangundang ... tetapi oleh van Hattum (I, hal. 243) ditegaskan bahwa "willen" itu tidak sama dengan "weten". Jadi "dengan sengaja" dan "willens en wetens" itu tidak sama pula ... seseorang yang hendak ("willen") berbuat sesuatu, belum tentu menghendaki juga akibat yang pada akhirnya (uiteindelijk) sungguh-sungguh ditimbulkan karena perbuatannya itu ... dalam praktek hukum pidana, maka hakim sangat sering mempersamakan dua pengertian ("willen en weten") yang tidak sama itu, yakni "dengan sengaja” meliputi juga "mengetahui" bahwa perbuatan yang dilakukan adalah suatu pelanggaran hukum. Jadi "mengetahui" itu sudah cukup untuk dapat diterima adanya "sengaja"."

Kedua, secara eksplisit Hakim Arief menyebut bentuk kesalahan berupa kesengajaan atau dolus. Sesungguhnya dalam basis teoritik Hiearij menyebut dan mengurai dalam sepuluh halaman bahwa ada delapan belas (18) jenis

43 Op.cit., Putusan Pengadilan Negeri Kotabumi, Pidana Khusus, Nomor 52/Pid.Sus/2016/PN.Kbu, Febri Anggara Alias Angga Bin Heri Nugroho, hlm. 24.

${ }^{44}$ E. Utrecht, Hukum Pidana I, Pustaka Tinta Mas, Surabaya, 1994, hlm. 209-300. 
kesengajaan. ${ }^{45}$ Sementara Amrani dan Mahrus membahas tiga (3) bentuk kesengajaan. ${ }^{46}$ Terlepas dari terbuktinya suatu tidak pidana bahwa in casu a quo bahwa pada titik ini, Hakim Arief miskin konsepsi. Tidak satu pun ia menyebut atau bahkan mengkualifikasikan bentuk kesengajaan. Padahal teori yang tidak teraplikasi akan berakibat pada mandeknya perkembangan ilmu pengetahuan hukum dan praktik hukum menjauh dari batasan akademik.

Ada dua hal yang penting untuk membahas sub judul pada bagian ini dalam mengkonstruksi pertimbangan hukum hakim in casu a quo: pertama, perihal parameter pembuktian menurut logika hukum pembuktian. Kedua, isu perlindungan hak asasi manusia dalam bidang peradilan. Biasa dikenal dengan istilah fair trial.

Secara lengkap: ${ }^{47}$

“... Menimbang, bahwa bertitik tolak dari apa yang dikemukakan di atas, maka untuk menentukan dan memastikan bersalah tidaknya Terdakwa dalam perkara ini dan untuk menjatuhkan pidana terhadapnya, Majelis Hakim akan berpegang teguh dan berpedoman kepada kesalahan Terdakwa harus terbukti dengan sekurangkurangnya "dua alat bukti yang sah" dan atas keterbuktiaan dengan sekurang-kurangnya dua alat bukti yang sah tersebut hakim harus pula "memperoleh keyakinan" (beyound a reasonable doubt) bahwa tindak pidana benar-benar terjadi dan bahwa Terdakwalah yang bersalah melakukannya."

Pada titik ini, Penulis menganalisis sebagai berikut: Kesatu, argumen di atas adalah perwujudan dari Pasal 183 Kitab Undang-Undang Hukum Acara Pidana (selanjutnya disebut KUHAP) yang dalam aras teoritik dikenal dengan istilah negatief wettelijk bewijstheorie (teori pembuktian negatif). Alasannya, "dasar pembuktian menurut keyakinan hakim yang timbul dari alat-alat bukti dalam undang-undang secara negatif," demikian kata Eddy 0. S. Hiearij. ${ }^{48}$ Kedua, kata-kata "dua alat bukti yang sah" dari sudut parameter pembuktian dikenal dengan istilah bewijs minimum. Kita mengetahui bahwa alat bukti yang sah berdasarkan Pasal 184 KUHAP yakni: keterangan saksi; keterangan ahli; surat; petunjuk; dan keterangan Terdakwa. Logika hukum pembuktian dalam bidang hukum apapun, dapat dikatakan hampir selalu mensyaratkan dua alat bukti sebagai minimum pembuktian, hanya saja dapat

\footnotetext{
${ }^{45}$ Eddy O. S. Hiearij, Prinsip .... op.cit., hlm. 172-182.

${ }^{46}$ Hanafi Amrani dan Mahrus Ali, Sistem ... op.cit., hlm., 37-38.

47 loc.cit., Putusan Pengadilan Negeri Kotabumi, Pidana Khusus, Nomor 52/Pid.Sus/2016/PN.Kbu, Febri Anggara Alias Angga Bin Heri Nugroho, hlm. 24.

${ }^{48}$ Eddy O. S. Hiearij, Teori dan Hukum Pembuktian, Erlangga, Jakarta, 2012, hlm. 17.
} 
berbeda jenis alat bukti dan hiearkinya. Bandingkanlah dengan alat bukti bidang hukum perdata menurut Pasal 164 Herzien Inlandsch Reglement (HIR) ${ }^{49}$ Perihal jenjang atau hiearki dalam alat bukti hukum pidana tidak ada. Namun, alat bukti saksi menjadi hal yang utama. Bahkan suatu kejahatan tidak akan terbukti di pengadilan tanpa adanya saksi yang dihadirkan secara sah di muka hakim. In casu a quo, sebagaimana argumentasi Hakim Arief yang menyatakan Penuntut Umum tidak mampu mengajukan saksi fakta. ${ }^{50}$ Sementara Penuntut Umum hanya menghadirkan saksi-saksi yang terkualifikasi sebagai testimonium de auditu. Ketiga, anak kalimat yang menyatakan "Majelis Hakim akan berpegang teguh dan berpedoman kepada kesalahan Terdakwa" menjadi menarik. Menurut pendapat Penulis, Hakim Arief perpegang teguh pada konsep dualistis hukum pidana. Konsekuensinya, in casu a quo, Hakim Arief pertama sekali memeriksa apakah suatu tindak pidana betul-betul telah terjadi dan dilakukan oleh Terdakwa.

Selanjutnya, kesalahan yang menjadi episentrum pertanggungjawaban pidana dalam konsep dualistis hukum pidana mempunyai konsekuensi dalam ranah praktik peradilan pidana. Hakim Arief sepanjang pertimbangan hukumnya tidak memeriksa kesalahan Terdakwa karena memang tidak perlu demikian. Tegasnya, Hakim Arief taat asas. Sebab tidak adil mempertanyakan Terdakwa memiliki kesalahan atau tidak bila tindak pidana pun tidak terbukti.

Jalan pikiran Hakim Arief pada akhirnya sebangun dengan perlindungan hak asasi manusia, khususnya prinsip fair trial. Dalam pertimbangannya, Hakim Arief berdalil: ${ }^{51}$

“... Menimbang, bahwa kesemuanya ini penting untuk menjamin tegaknya kepastian hukum, keadilan dan kebenaran serta perlindungan terhadap hak-hak asasi manusia (human rights), dan dengan tetap menjunjung tinggi asas praduga tak bersalah (presumption of innocent) di negara kita, sebagai negara berdasar atas hukum."

Peradilan pidana memang syarat benturan dengan hak asasi manusia dengan mengingatkan karakter hukum pidana yang keras dan menjatuhkan nestapa. Maka, ide perlindungan hak asasi manusia menjadi sorotan. Penulis berpegang teguh pada penjelasan Pasal 2 KUHAP Jo. Pasal 3 KUHAP yang intinya bahwa peradilan pidana dijalankan berdasarkan undang-undang sembari berpatokan pada asas-asas hukum pidana. Oleh sebab itu, asas legalitas berfungsi sebagai perlindungan hak asasi manusia sekaligus

49 Alat-Alat bukti, yaitu: bukti dengan surat; bukti dengan saksi; persangkaanpersangkaan; pengakuan; sumpah. Lihat R. Soesilo, RIB/HIR Dengan Penjelasan, Politeia, Bogor, 1995, hlm. 121.

50 Op.cit., Putusan Pengadilan Negeri Kotabumi, Pidana Khusus, Nomor 52/Pid.Sus/2016/PN.Kbu, Febri Anggara Alias Angga Bin Heri Nugroho, hlm. 33.

${ }^{51}$ Ibid., lengkapnya lihat Putusan Nomor 52/Pid.Sus/2016/PN.Kbu, hlm. 24. 
membatasi kekuasaan pemerintah untuk menghukum. Dengan perkataan lain, asas legalitas menjadi dasar pula dalam bangunan hukum pidana formil. Masih terkait pembuktian, Penulis menyadur pertimbangan hukum Hakim Arief sebagai berikut: ${ }^{52}$

“... Menimbang bahwa berdasarkan Undang-Undang Perlindungan Anak bahwa anak haruslah (diutamakan) dilindungi akan tetapi perlindungan tersebut tidaklah serta merta mengabaikan dan mengurangi hak-hak asasi warga negara lainnya dan mengingat pula unsur tindak pidana dari Pasal 81 ayat (2) UU No. 35 Tahun 2014 tentang perubahan atas Undang-Undang Republik Indonesia No. 23 tahun 2002 tentang Perlindungan Anak ini sendiri bahwa perlunya dibuktikan perbuatan kesengajaan dari Terdakwa melakukan tipu muslihat, serangkaian kebohongan atau membujuk anak melakukan persetubuhan dengannya, sehingga Majelis Hakim berpendapat rumusan ini bermakna yang perlu dibuktikan adalah perbuatan dan bukan hanya peristiwa persetubuhnnya."

Berdasarkan argumentasi teoritik pada bagian terdahulu, Penulis berpendapat bahwa pertama, Hakim Arief menjaga betul asas praduga tidak bersalah yang merupakan salah satu asas penting dalam KUHAP. Apa makna adagium ini? "Maknanya ialah semua hak-hak orang itu masih ada padanya sampai ada putusan hakim yang menjadi tetap, bahwa dia bersalah," begitulah kata Andi Hamzah. ${ }^{53}$ Bila pertimbangan hukum di atas ditelisik lebih jauh, telah nyata berhadapan-hadapan asas hukum seperti asas-asas dalam rezim hukum anak ${ }^{54}$ dengan asas equality before the law.

Kedua, dalam perspektif hak asasi manusia, prinsip ini dikenal dengan fair trial. Masih terkait prinsip praduga tidak bersalah, konkretnya di atur dalam Pasal 8 ayat (1) Undang-Undang Nomor 48 Tahun 2009 Tentang Kekuasaan Kehakiman ${ }^{55}$ jounto Pasal 14 ayat (2) Kovenan Internasional Hak Sipil dan Politik yang telah diratifikasi oleh Indonesia melalui Undang-Undang Nomor 12 Tahun 2005. ${ }^{56}$ Ketiga, dalam parameter pembuktian terdapat istilah bewjislast. In casu a quo, secara an sich Penuntut Umum dibebani pembuktian

52 Ibid., Putusan Pengadilan Negeri Kotabumi, Pidana Khusus, Nomor 52/Pid.Sus/2016/PN.Kbu, Febri Anggara Alias Angga Bin Heri Nugroho, hlm. 35-36.

${ }^{53}$ Andi Hamzah, Perlindungan Hak-Hak Asasi Manusia Dalam Hukum Acara Pidana: Perbandingan Dengan Beberapa Negara, Universitas Trisakti, Jakarta, 2010, hlm. 26.

54 Indonesia, Undang-Undang Nomor 23 Tahun 2002 Tentang Perlindungan Anak, BAB II Pasal 2 di bawah titel Asas dan Tujuan menyebut: non diskriminasi; kepentingan yang terbaik bagi anak; hak untuk hidup, kelangsungan hidup, dan perkembangan; dan penghargaan terhadap pendapat anak.

${ }_{55}$ Indonesia, Undang-Undang Nomor 48 Tahun 2009 Tentang Kekuasaan kehakiman, Pasal 8 ayat (1) mengatur: "Setiap orang yang disangka, ditangkap, ditahan, dituntut, atau dihadapkan di depan pengadilan wajib dianggap tidak bersalah sebelum ada putusan pengadilan yang menyatakan kesalahannya dan telah memperoleh kekuatan hukum tetap."

${ }^{56}$ Indonesia, Undang-Undang Nomor 12 Tahun 2005, Pasal 14 ayat (2) berbunyi: Setiap orang yang dituduh melakukan kejahatan berhak dianggap tidak bersalah sampai kesalahannya dibuktikan menurut hukum. 
khusunya bagian inti delik yang menjadi dakwaannya berdasarkan asas actori incumbit onus probandi. Artinya, siapa yang menuntut ialah yang membuktikan. Apabila Pentuntut Umum tidak dapat membuktikan dakwaan dan tuntutannya maka Terdakwa melalui putusan hakim pidana terdapat dua kemungkinan: putusan bebas (vrijspraak) dan lepas dari segala tuntutan hukum. Keempat, dengan mengingat definisi perbuatan pidana dan elemen perbuatan pidana maka penulis berpendapat yang mesti dibuktikan adalah perbuatan yang mesti dimengerti baik perbuatan aktif atau perbuatan pasif dan bukan peristiwa (kontra definisi dengan Abidin perihal arti kata strafbaar).

Kelima, harus pula disampaikan bahwa dengan melihat kembali konsep melawan hukum dalam hukum pidana dihubungkan dengan delictbestandeelen Pasal 81 ayat (2) Undang-Undang Nomor 35 Tahun 2014 sesungguhnya terkategorisasi sebagai delik formil. Hukum disini mesti dimengerti sebagai undang-undang. Oleh sebab itu, hal-hal yang mengecualikan untuk tidak dikatakan melawan hukum mesti ada pula dalam undang-undang.

\section{Penutup}

\section{Simpulan}

Berdasarkan uraian di atas, Penulis berkesimpulan dua (2) hal bahwa: Majelis Hakim dalam pertimbangan hukum terpilih memiliki dasar teoritis dalam mengkonstruksi alasan hukumnya. Dalam hal ini Majelis Hakim menggunakan teori dualistis dalam hukum pidana. In casu a quo, Majelis Hakim dalam uraian pertimbangan hukum terpilih bahwa tercermin perspektif hukum pembuktian yang taat asas dan taat hukum yang karenanya sebangun dengan konsep perlindungan hak asasi manusia, khususnya konsep fair trial.

\section{Saran}

Kepada para penegak hukum khususnya hakim Seharusnya tidak perlu membangun argumentasi sosial dalam konteks penilaian keseharian saksi korban dalam merumuskan usia anak yang bukan lagi dewasa dari segi biologis atau dalam hal ketika Majelis Hakim menilai profesi saksi korban. Seharusnya Majelis Hakim kembali kepada penafsiran hukumnya sendiri. Seharusnya, ketika menjelaskan dan menguraikan unsur-unsur delik, konsep kesalahan dan menyebut bentuk kesalahan Majelis Hakim dapat memperdalam argumentasinya dengan mengutip doktrin para pakar hukum pidana terkemuka. Padahal, doktrin diakui sebagai sumber hukum formal dalam ilmu hukum yang diajarkan di Fakultas Hukum seluruh Indonesia. 


\section{Daftar Pustaka}

\section{Buku}

Amrani, Hanafi dan Mahrus Ali, "Sistem Pertanggungjawaban Pidana Perkembangan dan Penerapan," Rajwali Pers, Jakarta, 2015.

Ali, Mahrus, “Dasar-Dasar Hukum Pidana," Sinar Grafika, Jakarta, 2011.

Farid, Andi Zainal Abidin, “Hukum Pidana I," Sinar Grafika, Jakarta, 1995.

Schaffmeister, D., N. Keizer, dan E. PH. Sitorius, “Hukum Pidana," Citra Aditya Bakti, Bandung, 2007.

Hamzah, Andi, "Perlindungan Hak-Hak Asasi Manusia Dalam Hukum Acara Pidana: Perbandingan Dengan Beberapa Negara," Universitas Trisakti, Jakarta, 2010.

Sinar Grafika, Jakarta, 2015

Hiearij, Eddy O. S., “Asas Legalitas \& Penemuan Hukum Dalam Hukum Pidana," Erlangga, Jakarta, 2009.

2012.

"Teori dan Hukum Pembuktian," Erlangga, Jakarta, "Prinsip-Prinsip Hukum Pidana," Cahaya Atma Pustaka,

Yogyakarta, 2016.

Huda, Chairul, "Dari Tiada Pidana Tanpa Kesalahan Menuju Kepada Tiada Pertanggungjawaban Pidana Tanpa Kesalahan: Tinjauan Kritis Teori Pemisahan Tindak Pidana dan Pertanggungjawaban Pdana," Kencana, Jakarta, 2013.

Kartanegara, Satochid, "Hukum Pidana," Balai Lektur Mahasiswa, tanpa kota, tanpa tahun.

Mertokusumo, Sudikno, “Penemuan Hukum Sebuah Pengantar," Liberty, Yogyakarta, 2009.

Moeljatno, “Asas-Asas Hukum Pidana,” Rineka Cipta, Jakarta, 2009.

Remmelink, Jan, “Hukum Pidana Komentar atas Pasal-Pasal Terpenting dari

Kitab Undnag-Undang Hukum Pidana Belanda dan Padanannya Dalam

Kitab Undang-Undang Hukum Pidana Indonesia," Gramedia Pustaka Utama, Jakarta, 2014.

Sapardjaja, Komariah Emong, “Ajaran Sifat Melawan-Hukum Materiel Dalam Hukum Pidana Indonesia," Alumni, 2002.

Saleh, Roeslan, "Perbuatan Pidana dan Pertanggungjawaban Pidana: Dua Pengertian Dasar Dalam Hukum Pidana,” Aksara Baru, 1983.

Soesilo, R., "RIB/HIR Dengan Penjelasan," Politeia, Bogor, 1995.

Sudarto, “Hukum Pidana I," Yayasan Sudarto, Semarang, 2018.

Utrecht, E., “Hukum Pidana I,” Pustaka Tinta Mas, Surabaya, 1994. 
Jurnal

Anisah, S., \& Raharjo, T. (2018). Batasan Melawan Hukum dalam Perdata dan Pidana pada Kasus Persekongkolan Tender. Ius Quia Iustum Law Journal, 25(1), 24-48.

Moeliono, T. P. (2015). Asas Legalitas dalam Hukum Acara Pidana: Kritikan terhadap Putusan MK tentang Praperadilan. Jurnal Hukum lus Quia lustum, 22(4), 594-616.

Ramadhan, C. (2018). Konvergensi Civil Law dan Common Law di Indonesia dalam Penemuan dan Pembentukan Hukum. Mimbar Hukum-Fakultas Hukum Universitas Gadjah Mada, 30(2), 213-229.

\section{Putusan Pengadilan}

Putusan Pengadilan Kotabumi Nomor 51/Pid.Sus/2016/PN.Kbu. Pidana Khusus. Febri Anggara Alias Angga Bin Heri Nugroho. 26 Juni 2016.

\section{Peraturan Perundang-Undangan}

Kitab Undang-Undang Hukum Pidana, penj. Moeljatno, Bumi Aksara, Jakarta, 2016.

Undang-Undang Nomor 8 Tahun 1981 Tentang Hukum Acara Pidana.

Undang-Undang Nomor 48 Tahun 2009 Tentang Kekuasaan Kehakiman.

Undang-Undang Nomor 35 Tahun 2014 Tentang Perlindungan Anak.

Undang-Undang Nomor 12 Tahun 2005 Tentang Pengesahan International Covenant On Civil And Political Rights (Kovenan Internasional Tentang Hak-Hak Sipil Dan Politik).

Surat Edaran Jaksa Agung Republik Indonesia Nomor SE-004/J.A/11/1993 tentang Pembuatan Surat Dakwaan, 16 Nopember 1993. 